\title{
Enhancement of Properties of Coir Geotextiles by Natural Rubber Latex Coating
}

\author{
Lekshmi Nair, P.K. Ravi, and U.S. Sarma*
}

\begin{abstract}
Coir geotextiles find application in revegetation of slopes by stabilizing the soil through erosion control. It has been found that the longevity of coir geotextiles although highest among all the natural fibres, it is required to last for at least 5 years so as to sustain the vegetation on the slopes for a long term solution. Normally it is found that coir geotextiles lose their $50 \%$ strength in 6 months in contact with soil, therefore it is required to strengthen the coir geotextiles.

This work involves the coating of coir geotextiles with natural rubber latex which could enhance the longevity of coir geotextiles in various civil/bio engineering applications. The rubber latex coated coir geotextiles which are eco-friendly have superior mechanical properties and better durability compared to the conventional uncoated coir geotextiles.

This paper reports the coating of coir geotextile using natural rubber latex and a comparative study of the physical and mechanical properties of the treated and untreated coir geotextiles.
\end{abstract}

Keywords: Coir geotextiles, latex coating, durability, physical properties, mechanical properties

\footnotetext{
* Corresponding author

Central Coir Research Institute, Kalavoor P.O, Alleppey, Kerala-688522, India.

E-mail:uss_2000@yahoo.com
} 


\section{Introduction}

Coir fibre is one of the widely used industrial fibre in the world of various industrial end uses. It has been characterized in terms of physical and mechanical properties (Samarawickrama, 2010). Coir Geotextiles, popularly known as "Coir mesh matting or Coir Bhoovastra", are permeable fabrics made from coir fibre. Due to the high lignin content of the natural coir fibres, these geotextiles are resistant to microbial attack (http://fao.org). These fibres decompose gradually and eventually disintegrate, leaving nothing but humus, which adds to the fertility of the soil. In this age of growing environmental awareness, coir geotextiles have become an ideal choice as natural geotextiles and are being widely used in various civil engineering applications. Coir geotextiles get decomposed with passage of time, therefore, are used for short term applications like soil erosion control on slopes, as a separator in unpaved roads etc. where durability is not a critical factor. However, coir geotextiles are found to degrade faster on rocky patches and very steep slopes where the vegetation takes a longer time to establish. The durability is found to be insufficient for reinforcement applications also. Therefore there is a need for enhancing the durability of coir geotextiles. As the geotextile applications are increasing day by day, new methods are needed to be introduced to enhance the durability of coir geotextiles to expand and improve its scope of utility. In this paper, a novel method has been introduced which involves the coating of the coir geotextiles with natural rubber latex for enhancing durability.

\section{Materials and Methods}

The coir geotextiles have been used in different forms for various field applications for control of soil erosion and rural unpaved roads (Ravi, 2007). The uncoated and latex coated test specimens were tested in order to evaluate the physical and mechanical properties. The values of mass per unit area for both coated and uncoated were utilised for the evaluation of latex pick up and water absorption test.
Since different constructions are suitable for different applications, coir geotextiles are produced in various sizes, shapes and weights. Coir geotextiles are classified into two main categories - the woven and the non-woven

Woven coir geotextiles are developed from coir yarn using different weaving techniques. The weaving process gives these geotextiles an appearance of two sets of parallel threads which are made by the alternate interlacing of the warp and weft strands, and classified into different categories based on their weights per square meter. These coir geotextiles are two shaft handloom mattings having mesh sizes from 0.6 cm to $2 \mathrm{~cm} . \mathrm{H}_{2} \mathrm{M}_{5}, \mathrm{H}_{2} \mathrm{M}_{6}$ are two such types with mass $700 \mathrm{~g} / \mathrm{m}^{2}$ and $400 \mathrm{~g} / \mathrm{m}^{2}$ with an apparent opening size of $7.5 \mathrm{~mm}$ and $20 \mathrm{~mm}$ respectively, which were chosen for the experiments. In $\mathrm{H}_{2} \mathrm{M}_{5}$ and $\mathrm{H}_{2} \mathrm{M}_{6}$ both, the warp yarn and weft yarn are of Vycome type which is a type of yarn made only in the Vycome region (comprising of Alleppey, Kottayam and Ernakulam districts) in the state of Kerala in India. Vycome yarn is a loose twist yarn of twist varying from 12 to 16 per foot . The yarn is produced by retting of coir fibre in backwaters, lakes and lagoons and subsequently extracting the fibre by mechanical means. The Central Coir Research Institute has recently developed a mobile fibre extracting machine which can directly extract the coir fibre from natural green mature husk to yield fibre in a matter of 10 seconds. The fibre thus produced is subjected to treatment with COIRRET, a bacterial formulation to produce retted quality fibre. The extracted fibres are spun on traditional motorised ratts to produce loose twist Vycome yarn of runnage varying from 200 to $300 \mathrm{~m} / \mathrm{kg}$.

The thin yarn geotextile made from very thin coir yarn of runnage $1000-1300 \mathrm{~m} / \mathrm{kg}$ has a mesh size of $5 \mathrm{~mm}$.

Non-woven Coir Geotextiles such as needled felt are formed by introducing fibres into a machine equipped with groups of specially designed needles that punch through the fibres and reorient them so that mechanical bonding is achieved among the individual fibres. The fibres used for the manufacture of 
four different coir materials in this study are mechanically extracted from green husk, using defibering machine which are further soaked in water for 3 days before conversion into yarn. These fibres are distinctly different from the mechanically extracted fibres produced in other parts of the country and in the neighbouring countries in the Asia Pacific region (Samarawickrama, 2010).

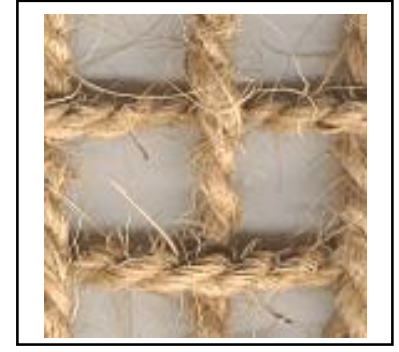

$\mathrm{H}_{2} \mathrm{M}_{6}$

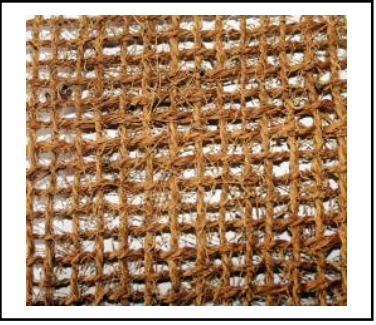

Thin yarn coir netting

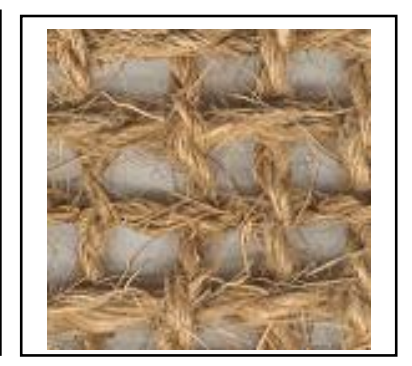

$\mathrm{H}_{2} \mathrm{M}_{5}$

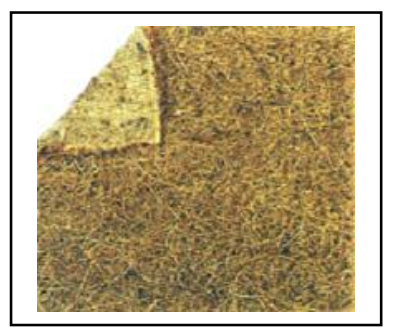

Coir Needled Felt
Above four different types of coir geotextiles namely $\mathrm{H}_{2} \mathrm{M}_{5}, \mathrm{H}_{2} \mathrm{M}_{6}$, non woven needled felt and thin yarn coir netting has been used for carrying out coating. The tests were conducted at room temperature. The four different types of coir geotextiles were tested for the physical and mechanical properties like mass per unit area, thickness, breaking strength, water absorption etc. The latex was coated on these geotextiles with the help of a hand sprayer. It was then dried and the coated samples were again tested and the changes in properties were noted. For a better understanding of the variations in properties, the experiments were conducted in 5 trials.

1. Mass per unit area: The mass per unit area was determined by weighing small square specimens of known dimensions (IS: 15868(Part 1 to 6): 2008). Ten specimens of
$100 \mathrm{~cm}^{2}$ were cut from the material in such a way that they are representatives of the material to be tested. The mass per unit area of each specimen was calculated using the equation and the average was noted.

$$
p=(m \times 106) / a
$$

Where

$$
\begin{aligned}
& \mathrm{p}=\text { mass/unit area in } \mathrm{g} / \mathrm{m}^{2} \\
& \mathrm{~m}=\text { mass of the specimen in, } \mathrm{g} \\
& \mathrm{a}=\text { area of the specimen in } \mathrm{mm}^{2}
\end{aligned}
$$

2. Thickness: The distance between a reference plate on which the specimen rests and a parallel presser-foot applying the given pressure to the specimen is defined as the thickness of the geotextiles. A thickness test apparatus capable of exerting a pressure of $2 \mathrm{kPa}$ was used. The specimen was placed between the surfaces of the reference plate and pressure foot of the thickness tester. The presser-foot was loaded gently over the specimen by applying a pressure of $2 \pm 0.01 \mathrm{kPa}$. The gauge reading was noted after 30 seconds. The procedure was repeated for ten specimens. The average of all the readings has been reported as the thickness of the geotextile.

3. Water Absorption: A galvanized screen and pans were used for the determination of water absorption. Three specimens measuring $200 \mathrm{~mm} \times 200 \mathrm{~mm}$ were prepared and weighed to the nearest $0.1 \mathrm{~g}$. Each specimen was placed on a galvanized wire screen. Another tared screen having similar dimension was placed over the specimen. Both screen and the specimen were placed in a $76 \mathrm{~mm}$ deep pan containing water at about $75 \mathrm{~mm}$ depth. The specimen was allowed to soak for 24 hours. After the soaking period the specimen and the screens were allowed to drain for 10 minutes and then weighed

The absorptive capacity is the ratio of the water held by the specimen to the weight of the original dry specimen. 
4. Wide Width Tensile Tests: A $100 \mathrm{kN}$ capacity Universal Testing Machine (Shimadzu Autograph-AG X/R), was used for conducting the test at a constant rate of traverse of $10 \mathrm{~mm} / \mathrm{min}$ and a fixed gauge length of $100 \mathrm{~mm}$ (ASTM D 4595-86). For each type of fabric, 5 specimens of dimensions $200 \mathrm{~mm}$ x $100 \mathrm{~mm}$ were prepared. The specimens were loaded until rupture and the breaking load at the time of rupture was noted. Test were conducted in both machine and cross machine direction.

The data generated by all these tests are furnished in Table 1

5. SEM studies: Scanning Electron Microscope studies of treated and untreated coir geotextiles were carried out on JoelJFM 8380 LV, Japan.

\section{Coating Method:}

About $1 \mathrm{~kg}$ of latex was mixed with $150 \mathrm{gm}$ of the compounding solution that is used for the manufacture of rubberized coir mattresses. The mixture was stirred well with the help of a mechanical stirrer for about 5 minutes. The geotextile sample was spread on the ground and the latex was sprayed on the surface of the geotextile with the help of a spray gun and compressor. After spraying on one side, it was exposed to sunlight for about 2 hours for drying. Then the other surface was also sprayed in a similar fashion and both the surfaces were made to pass through a drier at a temperature of $100^{\circ} \mathrm{C}$.

After proper drying, the four samples were weighed and the percentage weight gain due to coating, was calculated.

The geotextile samples were immersed in water for 24 hours before conducting the break load test in wet condition. The samples were then allowed to drain for about 10 minutes. After that, the break load test was conducted with the four types of coir geotextiles (Table 1).

\section{Results and Discussion}

The coated and uncoated coir geotextiles, which have a great potential in various civil engineering applications, were studied for different physical and mechanical properties [Table 1].

It is seen from the Table that the latex coated systems exhibit better mechanical properties than the uncoated ones. The latex coated coir geotextiles have shown to have better breaking strength which may be due to the greater adhesion achieved and better load transfer between the filaments offered by the coated materials. The coated coir needled felt showed an increase of about $433 \%$.

The increases in break loads were also analyzed for statistical significance. A matched pairs t-test was performed to determine the significance of the difference on break loads due to the rubber latex coating. It has been calculated that the gain in break load of coated $\mathrm{H}_{2} \mathrm{M}_{5}, \mathrm{H}_{2} \mathrm{M}_{6}$, coir needled felt and thin yarn coir geotextiles are statistically significant, where the values of $\mathrm{P}$ were found to be $0.04,0.03$, $0.003,0.03,0.0004,0.04$, and 0.003 in the warp and weft directions respectively. The strain was also found to increase in most of the cases.

The water absorption was very high in uncoated samples. Very high values led to substantial change in the physical and mechanical properties of geotextiles. The coated samples exhibited low water absorption. The decrease in water absorption due to the latex coating was also found to be statistically significant for all the four types of coir geotextiles where the values of $\mathrm{P}$ were found to be $0.001,0.003,0.001$, and 0.002 for $\mathrm{H}_{2} \mathrm{M}_{5}$, $\mathrm{H}_{2} \mathrm{M}_{6}$, coir needled felt and thin yarn coir geotextiles respectively. Therefore the coating is capable of restricting the changes which may be caused due to environmental conditions.

Graphical representations of the changes in water absorption are given in Figure 1.

The analysis of Variance (ANOVA) was also calculated for $\mathrm{H}_{2} \mathrm{M}_{5}, \mathrm{H}_{2} \mathrm{M}_{6}$, coir needled felt and thin yarn coir geotextiles used in this test. The $\mathrm{P}$ value which was found to be less than .001 showed that there was substantial variability between the different types of geotextiles used for the experiments. 
Table 1. Tested values for coated and uncoated coir geotextiles with natural rubber latex

\begin{tabular}{|c|c|c|c|c|c|c|c|c|c|}
\hline \multirow{2}{*}{\multicolumn{2}{|c|}{ Variable }} & \multicolumn{2}{|c|}{$\mathrm{H}_{2} \mathrm{M}_{5}$} & \multicolumn{2}{|c|}{$\mathrm{H}_{2} \mathrm{M}_{6}$} & \multicolumn{2}{|c|}{ Needled felt } & \multicolumn{2}{|c|}{ Thin yarn coir netting } \\
\hline & & Control & Coated & Control & Coated & Control & Coated & Control & Coated \\
\hline \multicolumn{2}{|c|}{$\begin{array}{l}\text { Mass per unit area, } \\
\mathrm{g} / \mathrm{m}^{2}\end{array}$} & 702.1 & 816.66 & 400 & 451 & 815 & 1072.59 & 400 & 600 \\
\hline \multicolumn{2}{|c|}{ Weight gain (\%) } & - & 16.66 & - & 12.90 & - & 31.5 & - & 50 \\
\hline \multicolumn{2}{|c|}{ Thickness, mm } & 7.763 & 7.915 & 7.32 & 8.00 & 12 & 14.57 & 4.0 & 4.70 \\
\hline \multirow[t]{2}{*}{$\begin{array}{l}\text { Wide } \\
\text { Width } \\
\text { Tensile } \\
\text { Tests, } \\
\text { kN/m } \\
\text { (Dry) }\end{array}$} & Warp & $\begin{array}{l}11.50 \\
8.33 \\
10.50 \\
12.17 \\
10.00 \\
\\
\text { Mean= } \\
10.50\end{array}$ & $\begin{array}{l}13.33 \\
13.16 \\
15.33 \\
12.16 \\
11.82 \\
\\
\text { Mean= } \\
13.16\end{array}$ & $\begin{array}{l}9.50 \\
8.33 \\
8.33 \\
9.16 \\
7.73 \\
\\
\text { Mean= } \\
8.61\end{array}$ & $\begin{array}{l}11.83 \\
10.00 \\
11.33 \\
10.33 \\
10.66 \\
\\
\text { Mean= } \\
10.83\end{array}$ & \multirow{2}{*}{$\begin{array}{l}0.04 \\
0.04 \\
0.00 \\
0.01 \\
0.01 \\
\text { Mean= } \\
0.02\end{array}$} & \multirow{2}{*}{$\begin{array}{l}1.33 \\
0.83 \\
0.833 \\
1.16 \\
1.16 \\
\\
\text { Mean= } \\
1.06\end{array}$} & $\begin{array}{l}7.30 \\
8.33 \\
7.83 \\
8.16 \\
10.0 \\
\\
\text { Mean= } \\
8.32\end{array}$ & $\begin{array}{l}10.83 \\
11.66 \\
12.5 \\
10.33 \\
9.33 \\
\\
\text { Mean= } \\
10.93\end{array}$ \\
\hline & Weft & $\begin{array}{l}11.56 \\
10.30 \\
10.85 \\
11.20 \\
12.34 \\
\text { Mean= } \\
11.25\end{array}$ & $\begin{array}{l}13.21 \\
12.83 \\
12.33 \\
12.33 \\
12.45 \\
\\
\text { Mean- } \\
12.63\end{array}$ & $\begin{array}{l}6.33 \\
4.33 \\
4.66 \\
6.33 \\
5.00 \\
\\
\text { Mean= } \\
5.33\end{array}$ & $\begin{array}{l}8.5 \\
9.66 \\
6.83 \\
7.33 \\
6.66 \\
\\
\text { Mean= } \\
7.80\end{array}$ & & & $\begin{array}{l}5.83 \\
5.66 \\
6.83 \\
6.66 \\
7.66 \\
\\
\text { Mean= } \\
6.53\end{array}$ & $\begin{array}{l}8.83 \\
10.16 \\
9.16 \\
11.50 \\
9.83 \\
\\
\text { Mean= } \\
9.90\end{array}$ \\
\hline \multirow{2}{*}{$\begin{array}{l}\text { Tensile } \\
\text { Strain } \\
(\%)\end{array}$} & Warp & 18.33 & 17.71 & 17 & 17.2 & \multirow[b]{2}{*}{6} & \multirow{2}{*}{18.8} & 15.2 & 18.8 \\
\hline & Weft & 18 & 17.44 & 13 & 17.04 & & & 16 & 17.2 \\
\hline \multirow{2}{*}{$\begin{array}{l}\text { Wide } \\
\text { Width } \\
\text { Tensile } \\
\text { Tests, } \\
\text { kN/m } \\
\text { (Wet) }\end{array}$} & Warp & 9.01 & 11.58 & 6.48 & 8.83 & \multirow{2}{*}{0} & \multirow{2}{*}{0.3} & 5.80 & 8.26 \\
\hline & Weft & 7.79 & 10.28 & 3.31 & 5.05 & & & 5.05 & 6.83 \\
\hline
\end{tabular}

Figure 1. Variation of Water Absorption on Treatment with Natural Rubber Latex

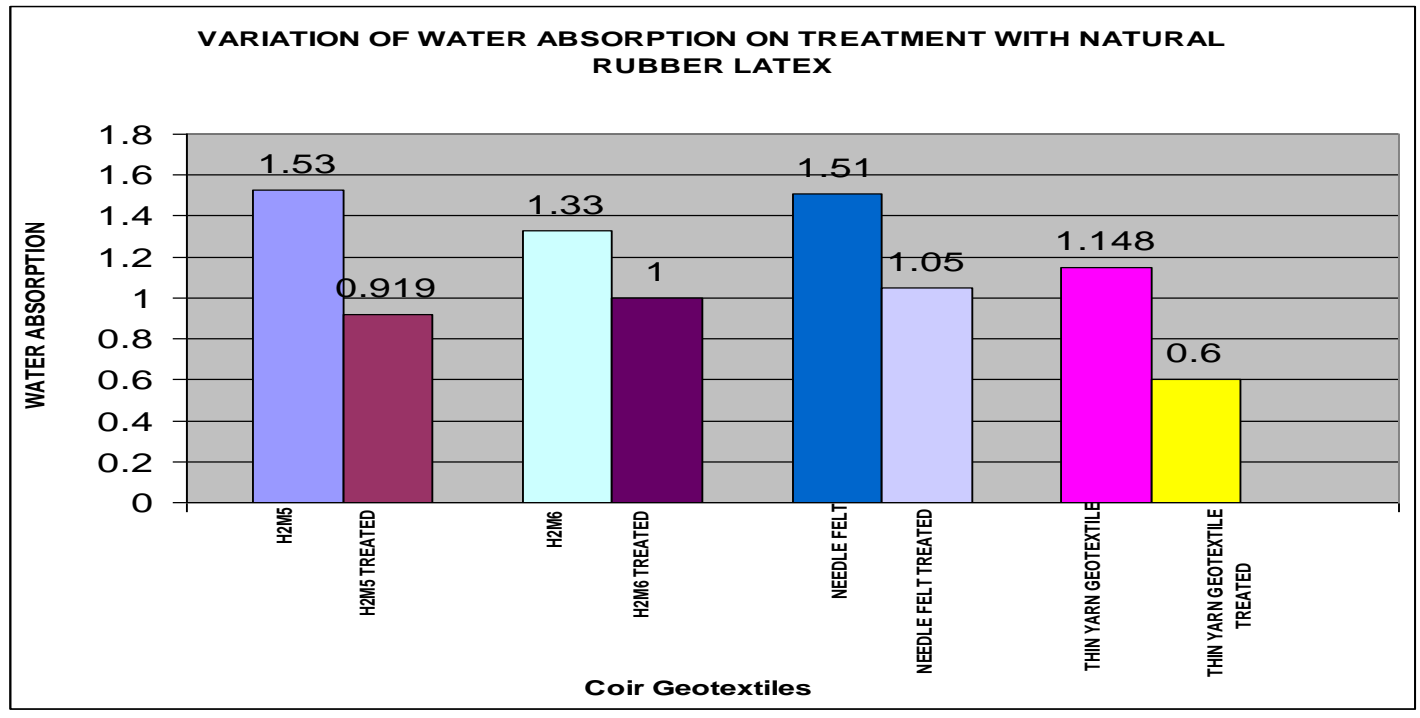


The use of different types of coir geotextiles gave a better understanding of the variation in properties. It has been found that the increase in water absorption is directly proportional to the quantity of coir fibre/yarn in the geotextile. The latex coating fills up the pores of the coir fibre therefore the water absorption is greatly reduced. The greater reduction in absorption is found in geotextiles like $\mathrm{H}_{2} \mathrm{M}_{5}$ and thin yarn coir netting which had high water absorption values in the uncoated state. Since the quantity of coir fibre/ yarn was least in $\mathrm{H}_{2} \mathrm{M}_{6}$, the reduction in the water absorption value was also found to be least in $\mathrm{H}_{2} \mathrm{M}_{6}$. The coir needled felt has loosely packed coir fibres and hence the number of strands of coir fibre are less and hence lesser value.

The percentage increase in the break loads of coated coir geotextiles is found to be directly on the initial break loads of the control/untreated samples. The changes in values of break loads are more or less the same in case of $\mathrm{H}_{2} \mathrm{M}_{5}, \mathrm{H}_{2} \mathrm{M}_{6}$ and thin yarn coir netting. $\mathrm{H}_{2} \mathrm{M}_{6}$ and thin yarn coir netting have lower initial values, therefore they show greater increase in break load after the latex coating. The non woven coir needled felt, however, showed an increase in break load of $433 \%$ after the latex treatment. In the uncoated state the non woven coir needled felt has only a weak mechanical bonding between the fibres which caused it to tear off easily at very low loads. The latex coating binds the fibres well together and comparatively a greater load in required to break the mechanical bonding. The above results indicate that the non woven coir needled felt showed an excellent improvement in the physical and mechanical properties after the latex treatment.

In the non coated coir needled felt the coir fibres are very loosely bound together and give way very easily during handling. The coated sample however has the coir fibres very well bound together with the latex as a result of which the non woven coir needled felt can be handled very easily without the fear of tearing the sample.

The break load in warp and weft direction in wet condition is much lower than the break load in dry condition. The break load measurement of coated and uncoated samples in wet had shown that the reduction percentage of the coir geotextile coated with latex was found to be lower than that of the uncoated coir geotextiles as in Table 2. This means that the treated samples have an enhanced protection from the changing environmental conditions. The break load of the coated coir needled felt sample in wet condition was found to be greater than the break load of the uncoated sample in dry condition.

The coir fibres used for this test were mechanically extracted and soaked in water for 4-5 days. These fibres were then spun into yarn which was then woven into coir geotextiles. Thus geotextiles which were produced in this way were used for the tests that were conducted. However the properties of coir fibre that has been studied in Characterisation and Properties of Sri Lankan coir fiber (Samarawickrama, 2010) was mechanically extracted. Since the fibres were extracted in two different ways a comparison cannot be made regarding their physical and mechanical properties.

It can be seen from the SEM micrographs that the pores on the surface of the coir fibres have been filled due to the coating of rubber latex, making it least vulnerable to wet conditions.

\section{Conclusion and Recommendation}

Latex coated coir geotextiles have been found to have excellent mechanical properties in comparison to the uncoated fabrics. The treated coir needled felt showed an increase in break load of about $433 \%$. Therefore, the latex coated fabrics can be used in place of uncoated fabrics for field applications which require higher durability

The latex coated samples exhibit low water absorption. Therefore the latex coated geotextiles may prove better than the uncoated ones for soil and water related applications.

The ends of the coir geotextiles have a tendency to open up whereas the coated geotextile fabrics remain intact thereby keeping all the strands in position. 
Table 2. The response to rubberizing of Water Absorption and Break Load coir geotextiles and their respective rates of deterioration after wetting

\begin{tabular}{|c|c|c|c|c|}
\hline Geotextile & $\begin{array}{l}\text { Decrease in Water } \\
\text { Absorption }\end{array}$ & $\begin{array}{l}\text { Increase in Break } \\
\text { Load }(\%)\end{array}$ & \multicolumn{2}{|c|}{$\begin{array}{l}\text { Deterioration of coated and } \\
\text { control samples after } \\
\text { wetting }(\%)\end{array}$} \\
\hline \multirow[t]{4}{*}{$\mathbf{H}_{2} \mathbf{M}_{5}$} & \multirow{4}{*}{40} & \multirow{2}{*}{25.33 (warp) } & \multirow[t]{2}{*}{ Warp } & 14 (control) \\
\hline & & & & 12(coated) \\
\hline & & \multirow{2}{*}{12.26 (weft) } & \multirow[t]{2}{*}{ Weft } & 30 (control) \\
\hline & & & & 18 (coated) \\
\hline \multirow[t]{4}{*}{$\mathbf{H}_{2} \mathbf{M}_{6}$} & \multirow{4}{*}{25} & \multirow{2}{*}{25.75 (warp) } & \multirow[t]{2}{*}{ Warp } & 30 (control) \\
\hline & & & & $24($ coated $)$ \\
\hline & & \multirow{2}{*}{46.34 (weft) } & \multirow[t]{2}{*}{ Weft } & 38 (control) \\
\hline & & & & 23 (coated) \\
\hline \multirow[t]{4}{*}{ Thin Yarn Coir Netting } & \multirow{4}{*}{48} & \multirow{2}{*}{31.20 (warp) } & \multirow[t]{2}{*}{ Warp } & 24 (control) \\
\hline & & & & 18 (coated) \\
\hline & & \multirow{2}{*}{51.60 (weft) } & \multirow[t]{2}{*}{ Weft } & 30 (control) \\
\hline & & & & 27 (coated) \\
\hline Coir Needled felt & 30 & 433 & & \\
\hline
\end{tabular}

Figure 2. SEM Micrograph of Untreated Natural Coir Fibre

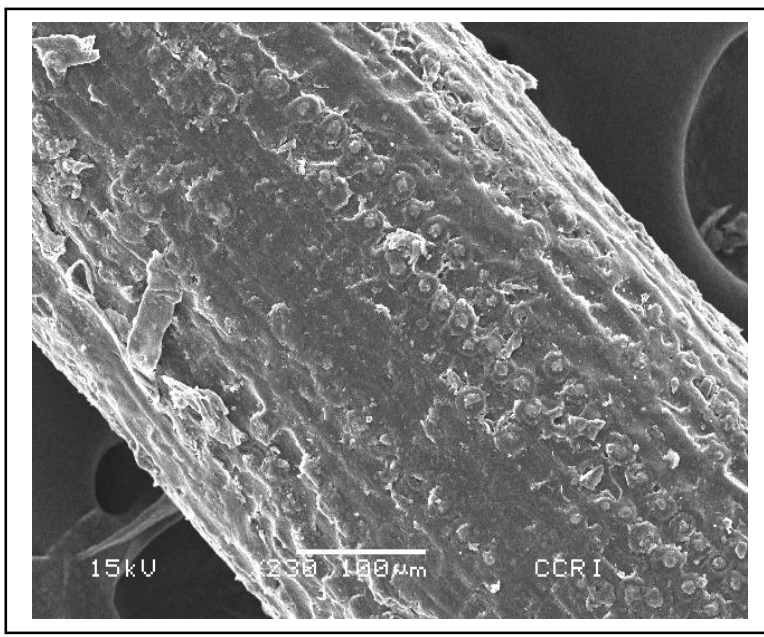

Figure 3. SEM Micrograph of Coir Fibre treated with rubber latex

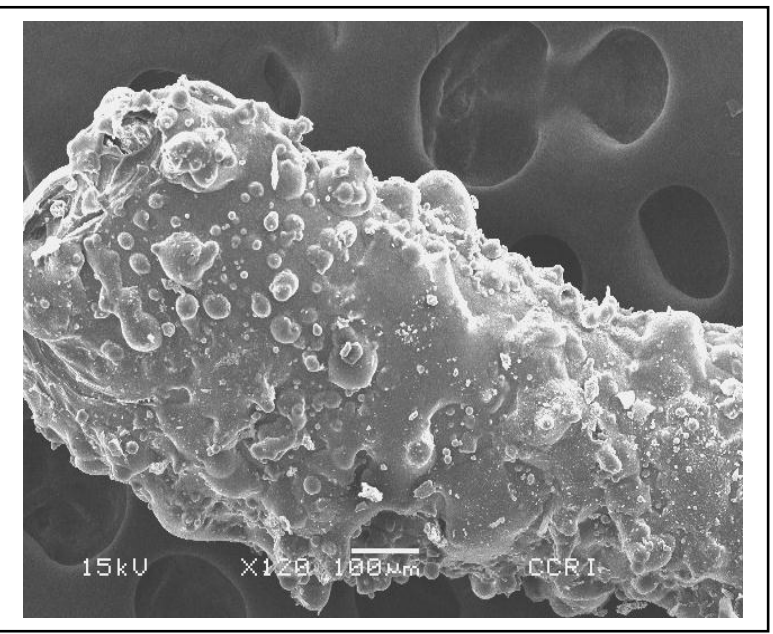

SEM Micrographs of treated and untreated coir fibre surfaces 
It was found that there was an increase of $30 \%$ in cost to produce latex coated coir geotextiles.

Field performance tests are scheduled to be conducted at regular intervals of time using the coated as well as uncoated coir geotextiles to check for the improvement in durability due to latex coating. After proper assessment a follow up report in the form of a second paper will be published in due course which will cover the improvement in durability in the field level.

\section{Acknowledgement}

Thanks are due to the Coir Board, Ministry of MSME, Govt. of India for providing funding support to engage Ms. Lekshmi Nair as Project Assistant. The keen interest and continuous encouragement of Mr. V. S. Vijayaraghavan, Ex. M. P. and Chairman, Coir Board is gratefully acknowledged.

\section{References}

Samaravickrama, D. S., 2010, Characterisation and Properties of Sri Lankan coir fiber, Cord 26(1).

http://www.fao.org/DOCREP/005/Y3612E/Y361 2e00.htm

IS: 15868(Part 1 to 6): 2008 Natural Fibre Geotextiles (Jute Geotextile and Coir Bhoovastra)-Method of Test.

ASTM D 4595-86: Standard Test Method for Tensile Properties of Geotextiles by the Wide Width Strip Method.

Ravi, P.K. (2007)-Indian Coir-A Reference Book, 61-81,1, Coir Board, Kochi. 